\title{
Microbial shelf life quality assessment of a sensory evaluated ready-to-serve Momordica charantia L. (Bitter Gourd) drink
}

\author{
P E Chern ${ }^{1}$, N A Mahyudin ${ }^{1 *}$, H Ghazali $^{1}$, N K Mahmud Ab Rashid ${ }^{2}$ \\ ${ }^{1}$ Department of Food Service \& Management, Faculty of Food Science and Technology, Universiti Putra Malaysia, 43400 UPM Serdang, Selangor, Malaysia, \\ ${ }^{2}$ Department of Food Science, Faculty of Food Science and Technology, Universiti Putra Malaysia, 43400 UPM Serdang, Selangor, Malaysia
}

\section{ARTICLE INFO}

Article history:

Received on: October 26, 2017

Accepted on: January 16, 2018

Available online: April 05, 2018

\section{Key words:}

Sensory evaluation,

Shelf life,

Microbial quality,

Ready-to-serve,

Momordica charantia L.,

Bitter gourd

\begin{abstract}
The bitter gourd, Momordica charantia L. (MC), is used to prepare a ready-to-serve (RTS) drink. The objective is to evaluate the sensory characteristics of the drink according to consumer acceptability and to investigate its microbial shelf life when prepared using untreated and boiled water and stored at different temperatures. MC was used to prepare five concentrations of RTS drink $(0.58,0.70,0.80,0.90$, and $1.00 \mathrm{~g} / \mathrm{mL})$ by water extraction of juice added with selected ingredients. The samples were given to 40 untrained panelists and are rated on a 7-point hedonic scale. Total plate count, enumeration of yeasts and molds and presumptive tests for coliform count and Escherichia coli were used in assessing the microbial quality. From the sensory evaluation, the most accepted concentration of the RTS drink is $0.80 \mathrm{~g} / \mathrm{mL}$ with an average score of 4.09 . High amount of microbial growth exceeding $4 \log \mathrm{CFU} / \mathrm{mL}$ was found after $24 \mathrm{~h}$ when stored at $28 \pm 2^{\circ} \mathrm{C}$. Mold growth was visible when stored at $28 \pm 2{ }^{\circ} \mathrm{C}$ after $48 \mathrm{~h}$. E. coli was presumptively present in the sample but not in water used for preparation. This formulation of RTS drink can be beneficial for targeted consumers and ensuring the microbial safety through proper production and storage.
\end{abstract}

\section{INTRODUCTION}

The consumption of natural fruit and vegetable juices has increased in recent years as opposed to caffeine-containing beverages such as coffee, tea, and carbonated soft drinks [1]. Ready-to-serve (RTS) drinks are being served to consumers in the form of prepared juice, pulp, puree, or concentrated juice from a sound mature fruit or even vegetables. The bitter gourd, Momordica charantia L. (MC) which has several types of nutrients such as Vitamin A and $\mathrm{C}$, phosphorous, and iron besides containing biologically active chemicals including glycosides, saponins, alkaloids, fixed oils, triterpenes, proteins, and steroids is used as a vegetable and a traditional medicine [2,3]. The flesh of the MC specifically also contains gallic acid, gentisic acid, catechin, chlorogenic acid, and epicatechin that can be a good source of antioxidants for application in the food system [4]. The usage of MC in drinks has been common in various cultures, for example, it is served as a tea in Chinese cuisines and in Panama whereby its leaves are steeped in hot water and strained to form tea used to treat malaria and diabetes [5].

Juices are one of the RTS drinks which are in high demand due to low sodium, cholesterol and fat and high in vitamins, polyphenols,

\footnotetext{
*Corresponding Author

N A Mahyudin, Department of Food

Service \& Management, Faculty of Food

Science and Technology, Universiti Putra

Malaysia, 43400 UPM Serdang, Selangor,

Malaysia.Email: norainy@upm.edu.my
}

and antioxidants [6]. It is prepared using simple extraction methods usually by squeezing the pulp of a certain fruit or vegetable to form an unclarified, clouded liquid. Juices are commonly diluted or blended for fresh juices that are too acidic or strongly flavored [7,8]. Due to the strong taste of the bitter gourd, it is a challenge to develop a formulation that is easily accepted by most consumers. This is due to the presence of the alkaloid momordicin in the fruit and leaves of $\mathrm{MC}$ that caused it to be not preferred by most people $[9,10]$.

Juices are becoming a mode for transmission of pathogens; spoilage microorganisms are also reported to be a cause of juice spoilage [6]. The heavy load of microbial content in the juice itself and also in other major ingredients such as water and sugar increases the chances for its spoilage and also a cause of gastrointestinal disorders [8]. In recent years, there has been an increase of outbreaks related to the consumption of raw fruits, vegetables, and unpasteurized juices [11]. Juices especially raw juices have become a vehicle in transmitting foodborne pathogens such as Escherichia coli O157, Salmonella, and Cryptosporidium and there is an increase in reported foodborne outbreaks associated with consumption of fruit juices [6]. The quality of water used in the preparation of juice has a great influence on the overall microbial quality of RTS drinks. Besides using water for the rinsing of fruits or vegetables, water is also added for diluting or blending fresh juices that are too acidic or too strongly flavored [7]. Many incidences of juice contamination had reported poor water quality used in rinsing and preparation of juices $[12,13]$. 
In this study, the MC is used to prepare an RTS drink with a minimal amount of processing techniques. A sensory evaluation was carried out to determine the acceptability of the RTS drink. It was hypothesized that by having a good formulation of the RTS drink, there will be higher acceptability among consumers. Finally, microbiological quality tests were carried out to observe the shelf life of the drink. The RTS drink was prepared using untreated water, and boiled water and the microbial quality of both prepared samples were evaluated. As the RTS drink only undergoes a minimal amount of processing, it is succumb to high perishability. It was predicted that the RTS drink prepared using boiled water and stored at low temperature will have the lowest microbial growth.

\section{MATERIALS AND METHODS}

\subsection{Preparation of RTS MC Drink}

The ripe fruit of $\mathrm{MC}$ of the Chinese variety obtained from a local market was sliced into approximately $1 \mathrm{~cm}$ thickness after removing its seeds. $\mathrm{MC}$ slices were soaked in rice washed water with asam keping (Garcinia atroviridis) for approximately $30 \mathrm{~min}$ as a debittering process. After rinsing with clean water, $\mathrm{MC}$ juice is extracted followed by adding brown sugar, artificial honey, low-fat yogurt, lime juice, and mint extract. Five different concentrations $(0.58,0.70,0.80,0.90$, and $1.00 \mathrm{~g} / \mathrm{mL})$ of the drink sample were prepared by increasing the amount of MC and served in amounts of approximately $15 \mathrm{~mL}$ for each sample. The concentration of $0.58 \mathrm{~g} / \mathrm{mL}$ was used as an initial concentration based on the essential amount of MC used in the original RTS formulation [14].

\subsection{Sensory Evaluation of RTS MC Drink}

Forty untrained panelists were randomly selected as the sample size. The drink samples were rated based on a 7-point hedonic scale [15], where one is to dislike extremely, followed by 2 - dislike moderately, 3 - dislike slightly, 4 - neither like nor dislike, 5 - like slightly, 6 - like moderately, and 7 - like extremely. Attributes that were tested include the appearance (color), aroma/smell, taste (flavor), texture, aftertaste (lingering bitterness after swallowing), and the overall acceptability. The sample concentration with the highest score was regarded as the most acceptable formulation and was used in the further investigation of the microbiological quality. Statistical analyses were carried out using IBM SPSS ${ }^{\circledR}$ (Statistical Program for the Social Sciences, Chicago, IL). Analysis of variance and Pearson's correlation coefficients was used to analyze average values, standard deviations and significant difference between means.

\subsection{Microbiological Quality of RTS MC Drink}

The drink sample with $0.8 \mathrm{~g} / \mathrm{mL}$ concentration was prepared using water processed through reversed osmosis, using both boiled and untreated water. Plain water with no drink sample preparation was used as the control, providing a total of 4 samples: Drink sample prepared using boiled water; drink sample prepared using untreated water, plain boiled water, and plain untreated water. All samples were kept in small glass bottles of $200 \mathrm{~mL}$ each at two different temperatures of $4 \pm 2{ }^{\circ} \mathrm{C}$ (refrigerated temperature) and $28 \pm 2{ }^{\circ} \mathrm{C}$ (tropical climate room temperature), respectively. Microbial tests were conducted on each sample daily for a period of 6 days (144 h) consecutively using methods that are modified from the U. S. Food and Drugs Administration Bacteriological Analytical Manual [16].

\subsubsection{Aerobic plate count}

An amount of $0.1 \mathrm{~mL}$ of the solution of each dilution $\left(10^{-1}-10^{-5}\right)$ was spread onto solidified plate count agar (Merck, Germany) using a bent glass rod then incubated at $35^{\circ} \mathrm{C}$ for $24 \mathrm{~h}$. Triplicates were performed for each dilution. Normal plates (30-300 colonies) were counted, plates with more than 300 colonies are recorded as too numerous to count, while plates $<30$ colonies are recorded as too few to count.

\subsubsection{Enumeration of yeasts and molds}

An amount of $0.1 \mathrm{~mL}$ of the solution of each dilution was spread onto solidified potato dextrose agar (Merck, Germany) added with $0.01 \%$ chloramphenicol (Calibiochem, Germany) using a bent glass rod then incubated at $25^{\circ} \mathrm{C}$ for $3-5$ days. Plates containing $10-150$ colonies were counted.

\subsubsection{Presumptive test of coliforms}

The 3-tube most probable number (MPN) test was being used. $1 \mathrm{~mL}$ of 3 consecutive dilutions $(1: 10,1: 100$, and 1:1000) of the sample was being inoculated into lauryl tryptose broth (Merck, Germany) containing inverted Durham tubes then incubated at $35^{\circ} \mathrm{C}$ for $24 \mathrm{~h}$. Tubes were examined for the positive gas formation, and MPN per gram was determined from the 3 tube MPN with 95\% confidence intervals.

\subsubsection{Presumptive test of $E$. coli}

The sample was streaked on solidified Levine Eosin Methylene Blue agar (Friendemann Schmidt, Australia) and was performed on triplicates. Plates were incubated at $35^{\circ} \mathrm{C}$ for $24 \mathrm{~h}$. The plates were examined for dark centered colonies with a green metallic sheen which establish the presumptive presence of E. coli.

\section{RESULTS AND DISCUSSION}

\subsection{Sensory Evaluation of RTS MC Drink}

The results of the sensory evaluation of the RTS drink are shown in Table 1. Among the five concentrations of the RTS drink, the most accepted concentration was $0.80 \mathrm{~g} / \mathrm{mL}$ with a mean score of 4.09 on a hedonic scale of $1-7$. As expected the least accepted concentration was $1.00 \mathrm{~g} / \mathrm{mL}$. The high score for $0.80 \mathrm{~g} / \mathrm{mL}$ was mostly due to the higher ratings of its appearance and texture, even though it was only average for the taste. The most accepted taste for the RTS drink was the original formulation with a concentration of $0.58 \mathrm{~g} / \mathrm{mL}$, as the taste gets bitter with increasing concentration. There was no significance $(P>0.05)$ for the score between the concentrations, and the standard deviation was very high. The most acceptable concentration of the RTS drink $(0.80 \mathrm{~g} / \mathrm{mL})$ was used to conduct the microbiological quality.

The sensory evaluation of bitter gourd RTS beverage produced by Satkar et al. [17] had showed very close scores among all parameters on a 9-point hedonic scale. All scores were above average at 7.3 for color and appearance, 7.3 for flavor, and 7.5 for taste, while overall acceptability was 7.6. In the formulating of dietetic soft drinks using bitter gourd polysaccharide by Aziz et al. [18] the sample using 7.5\% slices of bitter gourd scored the highest in terms of the taste. The functional and dietetic beverage from bitter gourd developed by Din et al. [10] reported that their formulation produced sensory properties ranking above the acceptable range, and was suggested that their best formulation was with $15 \%$ of bitter gourd extract. The RTS drink of this recipe had ranked average on most of the aspects, and like other studies have close scores among the concentration and parameters, and based on the hedonic scale, it was only liked slightly. The overall acceptance decreases as the concentration of the MC content in the drink increases which signifies that many of the panelists do not prefer high amounts of MC concentration and the taste was only acceptable to a certain amount of the panelist. In general, bitter-tasting foods are not 
Table 1: Sensory evaluation score on a hedonic scale of 1-7 of all attributes (appearance, aroma, taste, texture, aftertaste, and overall acceptability) and mean score of all attributes of the RTS drink with five concentrations $(0.58,0.70,0.80,0.90$, and $1.00 \mathrm{~g} / \mathrm{mL})$

\begin{tabular}{|c|c|c|c|c|c|c|c|}
\hline \multirow{2}{*}{$\begin{array}{l}\text { Concentration of MC } \\
\text { in RTS drink }(\mathrm{g} / \mathrm{mL})\end{array}$} & \multicolumn{6}{|c|}{ Attributes } & \multirow{2}{*}{$\begin{array}{l}\text { Mean score of } \\
\text { all attributes }\end{array}$} \\
\hline & Appearance (color) & Aroma/smell & Taste (flavor) & Texture & Aftertaste & Overall acceptability & \\
\hline 0.58 & 4.575 & 3.85 & 4.05 & 4.525 & 3.875 & 3.55 & $4.071 \pm 0.404$ \\
\hline 0.80 & 5.800 & 3.625 & 3.725 & 4.525 & 3.200 & 3.700 & $4.096 \pm 0.938$ \\
\hline 0.90 & 5.025 & 3.575 & 3.375 & 4.450 & 3.275 & 3.875 & $3.929 \pm 0.683$ \\
\hline 1.00 & 5.000 & 3.800 & 2.975 & 4.475 & 2.750 & 3.825 & $3.804 \pm 0.857$ \\
\hline
\end{tabular}

Results for each attribute are presented as mean for $n=40$, mean score of attributes presented as a mean and standard deviation, RTS: Ready-to-serve

in the likeness of most consumers, but certain foods or beverages with bitter taste are enjoyed by the public for example coffee. Bitterness had used to be a caution against toxicity; however, certain bitter-tasting foods such as cruciferous vegetable or green tea may be beneficial to health. Stein et al. [19] hypothesized that the degree an individual is exposed to bitter tasting foods can alter the degree of likeness toward it. Repeated exposure and the presence of other palatable taste are more likely to increase the degree of likeness.

\subsection{Microbiological Quality of RTS MC Drink}

The results for aerobic plate count of RTS drink are shown in Figure 1. There was a high increase in the amount of bacterial growth after 1 day of storage of the RTS drink when kept at room temperature of $28 \pm$ $2{ }^{\circ} \mathrm{C}$. The RTS drink kept in refrigerated conditions has $\log \mathrm{CFU} / \mathrm{g}$ that remained below 4.0 up to 2 days of storage. Due to the minimal amount of processing and preservation techniques, the RTS drink has a short shelf life and has to be served and consumed at most 2 days after its preparation and kept under refrigerated conditions.

The microbial load of molds and yeasts of the RTS drink is shown in Figure 2. Similarly, there was a significant increase in the amount of molds and yeasts on the $2^{\text {nd }}$ day of storage at room temperature. The growth increased significantly on the $4^{\text {th }}$ day for the RTS drink that was kept in refrigerated conditions $\left(4 \pm 2^{\circ} \mathrm{C}\right)$. The boiling of water is able to eliminate most foodborne pathogens but not effective at killing endospores [20]. Previous studies by Rosa et al. [21] had reported that there are minimal differences in water quality of untreated and boiled water also can account for the less significant results of reduced levels of contamination. These reasons may explain the higher growth amounts in the enumeration of molds and yeasts than the RTS drink prepared with untreated water.

The coliform MPN results [Table 2] showed that the total coliform count in samples stored at room temperature $\left(28 \pm 2{ }^{\circ} \mathrm{C}\right)$ reached up to $1100 \mathrm{MPN} / \mathrm{g}$ by the $2^{\text {nd }}$ day of storage which was the highest count recorded when prepared using both untreated water and boiled water. The coliform count for samples stored at refrigerated temperature $4 \pm 2^{\circ} \mathrm{C}$ was maintained at lower counts which ranged at $7-150 \mathrm{MPN} / \mathrm{g}$ prepared using untreated water and 3-210 MPN/g prepared using boiled water. The inconsistency of the MPN number for all samples can be accounted by the presence of the life coliform in the water used in the preparation of the sample at the same time growth of spoilage bacteria. Previous studies done on fresh-squeezed orange juice by Bagci and Temiz [22] showed that the coliform count of juice was within 1-4 $\log$ MPN/mL. However, total coliform count in the study by Leul and Kibret [23] on freshly squeezed mango and pineapple juice had ranges $9.2->1000 \mathrm{MPN} / \mathrm{mL}$ and $<3 \rightarrow 1100 \mathrm{MPN} / \mathrm{mL}$, respectively. Similar to total viable count and mold and yeasts enumeration, there is a high possibility of recontamination of boiled water during the preparation
Table 2: MPN per gram for the RTS drink prepared using untreated and boiled water stored at $4 \pm 2^{\circ} \mathrm{C}$ and $28 \pm 2^{\circ} \mathrm{C}$ for 6 days

\begin{tabular}{|c|c|c|c|c|}
\hline \multirow[t]{3}{*}{ Day } & \multicolumn{4}{|c|}{$\begin{array}{l}\text { MPN per gram for } 3 \text { tubes each at } 0.1,0.01 \text {, and } 0.001 \mathrm{~g} \\
\text { inocula }\end{array}$} \\
\hline & \multicolumn{2}{|c|}{$\begin{array}{l}\text { RTS drink prepared using } \\
\text { untreated water }\end{array}$} & \multicolumn{2}{|c|}{$\begin{array}{l}\text { RTS drink prepared } \\
\text { using boiled water }\end{array}$} \\
\hline & $4 \pm 2^{\circ} \mathrm{C}$ & $28 \pm 2^{\circ} \mathrm{C}$ & $4 \pm 2^{\circ} \mathrm{C}$ & $28 \pm 2^{\circ} \mathrm{C}$ \\
\hline 0 & 93 & 150 & 210 & 210 \\
\hline 1 & 93 & 1100 & 150 & 1100 \\
\hline 2 & 28 & 28 & 11 & 1100 \\
\hline 3 & 20 & 460 & 20 & 150 \\
\hline 4 & 28 & 1100 & 3 & 1100 \\
\hline 5 & 150 & 28 & 3 & 35 \\
\hline 6 & 7 & 7 & 210 & 1100 \\
\hline
\end{tabular}

Results of MPN per gram are based on table readings for 3 tubes each at $0.1,0.01$, and $0.001 \mathrm{~g}$ inocula with $95 \%$ confidence intervals, RTS: Ready-to-serve, MPN: Most probable number

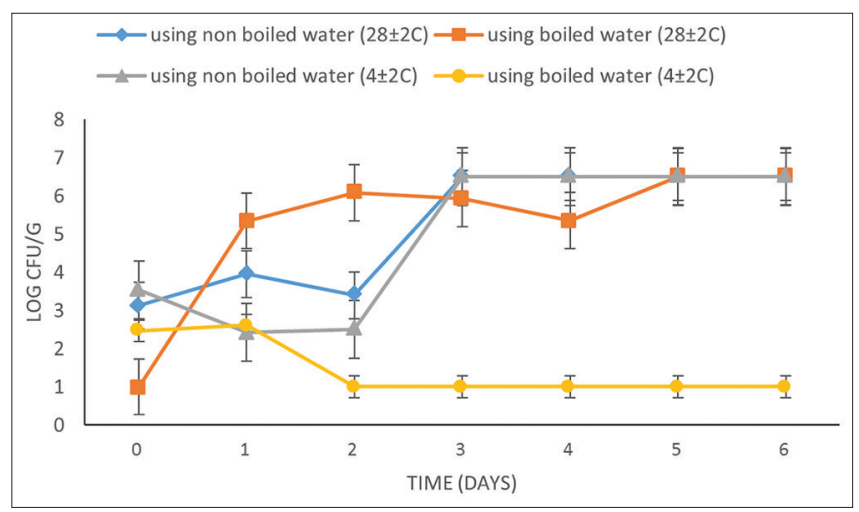

Figure 1: $\log \mathrm{CFU} / \mathrm{mL}$ for the aerobic plate count for ready-to-serve drink prepared using untreated and boiled water and stored in refrigerated $\left(4 \pm 2^{\circ} \mathrm{C}\right)$ and room temperature $\left(28 \pm 2^{\circ} \mathrm{C}\right)$ for 6 days

and handling of the sample when stored in smaller bottles [21]. The boiling of water using different utensils (electric kettle or pot) and the duration of boiling also influences the quality of the boiled water. As discussed by Cohen et al. [24], shorter boiling durations were associated with lower coliform counts, and electric kettles provide a more consistent and full pathogen inactivation and hence lesser secondary contamination. It was also uncertain if boiling of water alone is able to improve the quality of drinking water [24]. It can be concluded that the recontamination of boiled water caused the higher microbial load in the sample prepared with boiled water instead of untreated water. 
The presumptive presence of E. coli in the RTS bitter gourd drink using untreated and boiled water is shown in Table 3. There was no E. coli detected in the plain water used in the preparation of MC drink; therefore, it can be determined that the source of $E$. coli was from the raw ingredient of bitter gourd. There was more growth of $E$. coli detected in the drink kept at room temperature $\left(28 \pm 2^{\circ} \mathrm{C}\right)$ compared to it being kept at refrigerated temperature $\left(4 \pm 2^{\circ} \mathrm{C}\right)$. In the study by Reddi et al. [25], on the microbiological quality of street vended fruit juices, it showed ranges of 1.1-2.0 and 2.6-2.9 $\log 10 \mathrm{CFU} / \mathrm{mL}$ of E. coli and fecal coliforms count, respectively, in grape, pineapple, sapota, and sweet lime juices. Another study conducted on the microbiological quality of fruit and vegetable juices in Nigeria by Ukwo et al. [26] showed similar amount of total count for total viable count, coliform count, fecal count and Staphylococcal count for vegetable juices than fruit juices, Salmonella was detected also in several samples. Al-Jedah and Robinson's [27] study had also showed the presence of microbial growth in juices with total colony count $\left(6.6 \times 10^{4}-1.2 \times 10^{7} \mathrm{CFU} / \mathrm{mL}\right)$, coliform count (not detected $-1.6 \times 10^{5} \mathrm{CFU} / \mathrm{mL}$ ) and yeasts and molds count (not detected $-4.0 \times 10^{4} \mathrm{CFU} / \mathrm{mL}$ ). Due to the addition of yogurt as one of the ingredients of the RTS drink, there was a high total aerobic count of the drink. Similar to viable plate counts of yogurt, lactic acid bacteria was most probably the dominant microflora that appears on the plate count [28]. Heat treatment, for example, pasteurization may not be a suitable option for the formulation of this RTS drink, as it was reported that the heating of yogurt for 10$15 \mathrm{~min}$ at $60^{\circ} \mathrm{C}$ will cause a reduction in its bacterial count by $97-$

Table 3: Presumptive presence of $E$. coli in the RTS drink at $4 \pm 2^{\circ} \mathrm{C}$ and $28 \pm 2^{\circ} \mathrm{C}$ for 6 days

\begin{tabular}{ccccc} 
Day & \multicolumn{2}{c}{$\begin{array}{c}\text { Juice prepared using } \\
\text { untreated water } \\
\mathbf{4} \pm \mathbf{2}^{\circ} \mathrm{C}\end{array}$} & $\mathbf{2 8} \pm \mathbf{2}^{\circ} \mathrm{C}$ & \multicolumn{2}{c}{$\begin{array}{c}\text { Juice prepared using } \\
\text { boiled water }\end{array}$} \\
& - & + & - & - \\
0 & - & - & - & + \\
1 & - & - & - & + \\
2 & - & + & - & + \\
3 & - & - & - & - \\
4 & - & - & - & - \\
5 & - & - & - & - \\
6 & - & - & - & + \\
\hline
\end{tabular}

Results are shown as positive or negative performed on triplicates, RTS: Ready-to-serve, E. coli: Escherichia coli

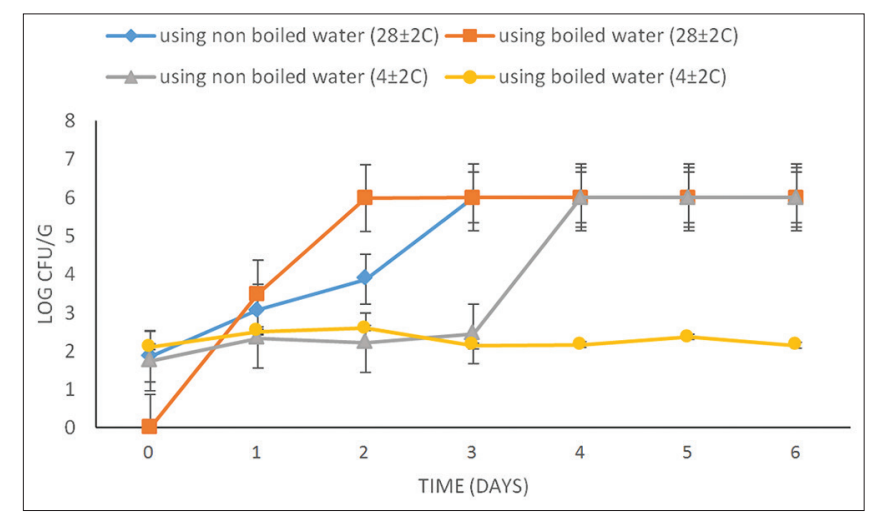

Figure 2: $\log \mathrm{CFU} / \mathrm{mL}$ for the enumeration of molds and yeasts for readyto-serve drink prepared using untreated and boiled water and stored in refrigerated $\left(4 \pm 2^{\circ} \mathrm{C}\right)$ and room temperature $\left(28 \pm 2^{\circ} \mathrm{C}\right)$ for 6 days
99\% [29]. Other foodborne pathogens possibly present in RTS drinks are Staphylococcus aureus as it is widely present in the environment and could also be contamination from food handlers. Some molds and yeasts such as Mucor sp., Aspergillus niger, Aspergillus flavus, and Saccharomyces sp., which are regular food spoilage microorganisms that easily contaminate fresh produce [7].

Yeasts spoilage are often the main cause in microbial quality deterioration of juices due to the high sugar content in juices and the tolerability of molds and yeasts in acidic conditions [30]. Compared to bacterial contamination in the RTS drink that is unobservable, molds, and yeasts growth can be easily observed in the product and can be detected more easily allowing them to function as an indicator for quality of raw materials [6]. Some other spoilage signs that can be observed in fruit juice are formation of haze, production of carbon dioxide and off-odors and as well as changes in color [31]. Acid tolerant bacteria are also mostly present due to low $\mathrm{pH}$ and have been reported to be a deteriorative in juices which causes off flavor [6].

Plant-based ingredients can be easily contaminated by E. coli due to its frequent contact to soil. According to Franz and van Bruggen [32], plants can serve as a carrier for human enteric pathogens such as $E$. coli O157:H7 and Salmonella enterica serovars especially in the production of leafy green vegetables. Raghubeer and Matches [33] conducted tests showing that the temperature range for growth of $E$. coli $\mathrm{O} 157: \mathrm{H} 7$ was at $24.3-41.0^{\circ} \mathrm{C}$ at $24 \mathrm{~h}$ and $19.3-41.0^{\circ} \mathrm{C}$ at $36 \mathrm{~h}$ and $48 \mathrm{~h}$. Therefore, the refrigerated temperature of $4 \pm 2{ }^{\circ} \mathrm{C}$ had inhibited the growth of E. coli in the RTS drink. The presence of foodborne pathogens in juice has led to foodborne outbreaks due to its consumption, especially in fruit juices. In most cases from 1991 to 2010, the outbreaks were due to unpasteurized juice [6]. Pasteurization is recommended for fruit juice at $90-95^{\circ} \mathrm{C}$ for $4-10 \mathrm{~s}$ as it is effective in reducing $E$. coli and Salmonella, it is however not effective against heat-resistant fungi and bacteria [6]. At the same time, thermal pasteurization causes nutritional loss and other physicochemical damages to the juice, such as in this study the taste of the MC drink was not desirable after heating. Certain consumers also prefer unpasteurized juice for its "fresh flavor [7]."

A study by Radke-Mitchell and Sandine [34] provided an optimum growth temperature range for Lactobacillus bulgaricus at $35-42^{\circ} \mathrm{C}$ and for Streptococcus thermophilus at $43-46^{\circ} \mathrm{C}$, therefore explaining the high MPN count for the RTS drink stored at room temperature $28 \pm 2{ }^{\circ} \mathrm{C}$. The inconsistency of the MPN number for all samples can be accounted by the presence of the life culture and also the growth of spoilage bacteria. Therefore, the MPN method could not be used as a suitable indicator for determining the overall microbial safety of the RTS drink under this condition. The high amount of coliforms could also be due to a high water activity of the RTS drink, as high water activity encourages growth and survival of microorganisms [8].

In the preparation of RTS juices, water is added as part of extraction and for dilution of juices with flavors that are too strong. According to a study by Nonga et al. [7], juice vendors in the study group did not pasteurize the juice after preparation, and most of the vendors did not store in proper cold storage. There was also improper washing of utensils and waste receiving bins. They concluded that the improper cold storage did not provide sufficient cooling and encouraged microbial growth. It was also reported that water used for washing fruits and for preparation of juices came from sources such as wells and taps and up to $44.4 \%$ of the vendors did not boil water for juice dilution [7]. Water and environment are factors that may cause fungi contamination, especially in washing raw produce. High microbial counts were also reported due to the poor quality of water for dilution, 
unhygienic utensil washing methods and poor personal and domestic hygiene [8].

In the National Standard for Drinking Water Quality [35] by the Ministry of Health Malaysia under the Engineering Services Division, the accepted value of $E$. coli presence for the recommended raw water quality is $5000 \mathrm{MPN} / 100 \mathrm{ml}$, while for drinking water quality standards the maximum accepted value is 0 in $100 \mathrm{ml}$. This is also in compliance with the National Primary Drinking Water Regulations [36] by the United States Environmental Protection Agency whereby the maximum contaminant level (MCL) for total coliforms including fecal coliform and E. coli is at $5 \% \mathrm{mg} / \mathrm{L}$, and the MCL goal is at $0 \mathrm{mg} / \mathrm{L}$. Referring to these standards, the MC drink is not safe for consumption when kept for more than 1 day at room temperature $\left(28 \pm 2{ }^{\circ} \mathrm{C}\right)$ and when raw untreated water was used. It is recommended that boiled water is used in the preparation and the drink be kept refrigerated until served.

\section{CONCLUSION}

The sensory evaluation of a product is important in determining the acceptability among consumers. The most accepted concentration of the MC drink was $0.80 \mathrm{~g} / \mathrm{mL}$, having the highest average score compared to other concentrations which may be too bland or too bitter. The microbial quality of MC drink serves as a safety indicator of RTS drinks. Under refrigerated conditions $\left(4 \pm 2^{\circ} \mathrm{C}\right)$ the drink can maintain its microbial safety up to 2 days or within $48 \mathrm{~h}$ of preparation, while it does not past 1 day when left in room temperature. Storing RTS drinks in refrigerated conditions can suppress the growth of foodborne pathogens as well as spoilage molds and yeasts. The sanitary condition of raw materials in preparing RTS drinks; especially water and fresh ingredients have to be monitored to prevent from contaminating the product. The formulation of this RTS drink can be aimed at targeted consumers with concern for health issues or those who have interest in natural products. Education is important for food handlers in preparing and serving RTS products to prevent from foodborne pathogenic outbreaks.

\section{ACKNOWLEDGMENT}

This research was financially supported by the IPS Grant (GP-IPS/2015/9469200), Universiti Putra Malaysia.

\section{REFERENCES}

1. Waghray K, Gulla S, Kumar CS, Kumar MP, Kumar AA. Sensory quality and acceptability of fresh juices. Stud Home Community Sci 2012;6:179-81.

2. Grover JK, Yadav SP. Pharmalogical actions and potential uses of Momordica charantia: A review. J Ethnopharmacol 2004;93:123-32.

3. Raman A, Lau C. Anti-diabetic properties and phytochemistry of Momordica charantia L. (Cucurbitaceae). Phytomedicine 1996;2:349-62.

4. Horax R, Hettiarachchy N, Islam S. Total phenolic contents and phenolic acid constituents in 4 varieties of bitter melons (Momordica charantia) and antioxidant activities of their extracts. J Food Sci 2005;70:C275-80.

5. Anilakumar KR, Kumar GP, Ilaiyaraja N. Nutritional, pharmacological and medicinal properties of Momordica charantia. Int J Nutr Food Sci 2015;4:73-83.

6. Aneja KR, Dhiman R, Aggarwal NK, Aneja A. Emerging preservation techniques for controlling spoilage and pathogenic microorganisms in fruit juices. Int J Microbiol 2014;2014. Article ID: 758942, 14.
7. Nonga HE, Simforian EA, Ndabikunze BK. Assessment of physicochemical characteristics and hygienic practices along the value chain of raw fruit juice vended in Dar es Salaam City, Tanzania. Tanzan J Health Res 2014;16:1-12.

8. Ijah UJ, Ayodele HS, Aransiola SA. Microbiological and some sensory attributes of water melon juice and watermelon-orange juice mix. J Food Resour Sci 2015;4:49-61.

9. Thakur M, Sharma RK. Bitter gourd: Health properties and value addition at farm scale. Marumegh 2016;1:17-21.

10. Din A, Bukhari SA, Salam A, Ishfaq B. Development of functional and dietetic beverage from bitter gourd. Internet $\mathrm{J}$ Food Saf 2011;13:355-60.

11. Buck JW, Walcott RR, Beuchat LR. Recent trends in microbiological safety of fruits and vegetables. Plant Health Progress 2003;10:1094.

12. Tambekar DH, Jaiswal VJ, Dhanorkar DV, Gulhane PB, Dudhane MN. Microbial quality and safety of street vended fruit juices: A case study of Amravati city. Internet J Food Saf 2009;10:72-6.

13. Lewis JE, Thompson P, Rao BV, Kalavati C, Rajanna B. Human bacteria in street vended fruit juices: A case study of Visakhapatnam city, India. Internet J Food Saf 2006;8:35-8.

14. Ghazali H, Abdul Kadir SA, Mahpof SN, Mohd Shahrin FS, Sariman NU, Chern PE, et al. Copyright No.: 201612270829. Selangor, Malaysia: Universiti Putra Malaysia; 2016.

15. Lawless HT, Heymann H. Sensory Evaluation of Food: Principles and Practices. New York: Chapman \& Hall; 1998.

16. Bacteriological Analytical Manual (BAM). US Food and Drug Administration. Available from: http://www.fda.gov/Food/ FoodScienceResearch/LaboratoryMethods/ucm2006949.htm\#intro. [Last updated on 2017 Oct 20; Last cited on 2017 Oct 25].

17. Satkar KP, Kulthe AA, Chalke PR. Preparation of bitter gourd readyto-serve beverage and effect of storage temperature on its keeping quality. Bioscan 2013;8:115-7.

18. Aziz MG, Roy J, Sarker MS, Yusof YA. Isolation and use of bitter gourd polysaccharide in formulating dietetic soft drinks. Afr J Agric Res 2011;6:5314-9.

19. Stein LJ, Nagai H, Nakagawa M, Beauchamp GK. Effects of repeated exposure and health-related information on hedonic evaluation and acceptance of a bitter beverage. Appetite 2003;40:119-29.

20. Using Physical Standards to Control Microorganisms. Lumen Learning, Candela, Waymaker. Available from: https://www.courses. lumenlearning.com/microbiology/chapter/using-physical-methodsto-control-microorganisms. [Last cited on 2017 Dec 05].

21. Rosa G, Miller L, Clasen T. Microbiological effectiveness of disinfecting water by boiling in rural Guatemala. Am J Trop Med Hyg 2010;82:473-7.

22. Bagci U, Temiz A. Microbiological quality of fresh-squeezed orange juice and efficacy of fruit surface decontamination methods in microbiological quality. J Food Prot 2011;74:1238-44.

23. Leul A, Kibret M. Bacteriological safety of freshly squezzed mango and pineapple juices served in juice houses of Bahir Dar Town, Northwest Ethiopia. Int J Sci Basic Appl Res 2012;6:24-35.

24. Cohen A, Tao Y, Luo Q, Zhong G, Romm J, Colford Jr JM, et al. Microbiological evaluation of household drinking water treatment in rural China shows benefits of electric kettles: A cross-sectional study. PloS One 2015;10:e0138451.

25. Reddi SL, Kumar RN, Balakrishna N, Rao VS. Microbiological quality of street vended fruit juices in Hyderabad, India and their association between food safety knowledge and practices of fruit juice vendors. Int J Curr Microbiol Appl Sci 2015;4:970-82.

26. Ukwo SP, Ndaeyo NU, Udoh EJ. Microbiological quality and safety evaluation of fresh juices and edible ice sold in Uyo Metropolis, South-South, Nigeria. Internet J Food Saf 2011;13:374-8.

27. Al-Jedah JH, Robinson RK. Nutritional value and microbiological safety of fresh fruit juices sold through retail outlets in Qatar. Pak J 
Nutr 2002;1:79-81.

28. Mataragas M, Dimitriou V, Skandamis PN, Drosinos EH. Quantifying the spoilage and shelf-life of yoghurt with fruits. Food Microbiol 2011;28:611-6.

29. Dagher S, Ali A. Effect of pasteurization, centrifugation and additives on quality of concentrated yogurt (Labneh). J Food Prot 1985;48:300-2.

30. Edwards CG, Haag KM, Collins MD, Hutson RA, Huang YC. Lactobacillus kunkeei sp. nov.: A spoilage organism associated with grape juice fermentations. J Appl Microbiol 1998;84:698-702.

31. Tournas VH, Heeres J, Burgess L. Moulds and yeasts in fruit salads and fruit juices. Food Microbiol 2006;23:684-8.

32. Franz E, van Bruggen AH. Ecology of E. coli O157: H7 and Salmonella enterica in the primary vegetable production chain. Crit Rev Microbiol 2008;34:143-61.

33. Raghubeer EV, Matches JR. Temperature range for growth of Escherichia coli serotype O157: H7 and selected coliforms in E. coli medium. J Clin Microbiol 1990;28:803-5.

34. Radke-Mitchell LC, Sandine WE. Influence of temperature on associative growth of Streptococcus thermophilus and Lactobacillus bulgaricus. J Dairy Sci 1986;69:2558-68.

35. Drinking Water Quality Standard. Drinking Water Quality Surveillance Programme, Engineering Services Division, Ministry of Health Malaysia; 2010. Available from: http://www.kmam.moh.gov. my/public-user/drinking-water-quality-standard.html. [Last cited on 2016 Nov 04].

36. National Primary Drinking Water Regulations (NPDWR). United States Environmental Protection Agency. Available from: https:// www.epa.gov/ground-water-and-drinking-water/table-regulateddrinking-water-contaminants\#one. [Last updated on 2017 Jul 11; Last cited on 2017 Oct 25].

\section{How to cite this article:}

Chern PE, Mahyudin NA, Ghazali H, Rashid NKMA. Microbial shelf

life quality assessment of a sensory evaluated ready-to-serve Momordica

charantia L. (Bitter Gourd) drink. J App Biol Biotech. 2018;6(3):47-52.

DOI: $10.7324 / J A B B .2018 .60308$ 